\title{
Analisis Dampak Pembangunan Terminal Kijing Terhadap Rencana Pengembangan Terminal Eksisting dan Biaya Transportasi
}

\author{
Nur Indra Suryani, Christino Boyke, dan Irwan Tri Yunianto \\ Departemen Teknik Transportasi Laut, Fakultas Teknologi Kelautan, \\ Institut Teknologi Sepuluh Nopember (ITS) \\ e-mail: irwan@seatrans.its.ac.id
}

\begin{abstract}
Abstrak-PT Pelabuhan Indonesia II (Persero) Cabang Pontianak saat ini sedang membangun terminal baru yaitu Terminal Kijing berdasarkan Peraturan Presiden Nomor: 43 Tahun 2017. Dengan adanya pembangunan Terminal tersebut, penelitian ini bertujuan untuk menganalisis adanya dampak dari pembangunan tersebut terhadap perubahan biaya transportasi muatan serta menganalisis rencana pendalaman alur di Terminal Peti Kemas (TPK) Dwikora (Terminal Eksisting). Penelitian ini menggunakan metode analisis perhitungan berdasarkan pada besar biaya transportasi. Hasil dari Penelitian ini yaitu; pertama, pendalaman alur di TPK Dwikora dapat menurunkan biaya transportasi muatan $8.1 \%$ pertahun yaitu sebesar $\mathrm{Rp} 81$ Miliar. Kedua, pembangunan Terminal Kijing dapat menurunkan biaya transportasi muatan 2\% pertahun yaitu Rp 17 Miliar. Ketiga, adanya pendalaman alur dan pembangunan Terminal Kijing dengan pembagian hinterland dapat menurunkan biaya transportasi muatan $8.4 \%$ pertahun yaitu $R p 85$ Miliar. Hinterland TPK Dwikora yaitu Kabupaten Sanggau, Ketapang, Sintang, Kapuas Hulu, Sekadau, Kubu Raya, dan Kota Pontianak. Hinterland Terminal Kijing yaitu Kabupaten Sambas, Bengkayang, Landak, dan Pontianak. Dari hasil diatas, rencana pendalaman alur di TPK Dwikora dan pembangunan Termina Kijing perlu dilakukan dengan biaya pendalaman alur sebesar Rp 709 Miliar dan investasi pembangunan Terminal Kijing untuk muatan peti kemas sebesar Rp 4.9 Triliun.
\end{abstract}

Kata Kunci-Biaya Transportasi Minimum, Pendalaman Alur, Terminal Kijing, Terminal Peti Kemas.

\section{PENDAHULUAN}

$\mathbf{M}^{-}$ UATAN peti kemas di Provinsi Kalimantan Barat megalami pertumbuhan rata-rata $15 \%$ tiap tahunnya terhitung dari tahun 2009 sampai tahun 2016. Dari jumlah arus peti kemas yang ada di Kalimantan Barat, rata-rata 59\% dari muatan peti kemas tersebut merupakan muatan Terminal Peti Kemas (TPK) Dwikora yang berada dibawah naungan PT Pelabuhan Indonesia II (Persero) Cabang Pontianak, hal ini menunjukkan bahwa arus muatan peti kemas di Kalimantan Barat berpusat di TPK Dwikora. Dengan kapasitas eksisting di TPK Dwikora sebesar 280,904 TEUs per Tahun, dan dengan meningkatnya arus peti kemas di Kalimantan Barat di beberapa tahun mendatang, TPK Dwikora tidak dapat mengakomodir pertumbuhan peti kemas tersebut sehingga diperlukan adanya pengembangan Terminal yang lain yaitu pengembangan Terminal Kijing yang nantinya memiliki kapasitas lebih besar.

Adanya pengembangan Terminal Kijing telah tertera dalam Peraturan Presiden (Perpres) Nomor: 43 Tahun 2017 [1] tentang Percepatan Pembangunan dan Pengoperasian Terminal Kijing Pelabuhan Pontianak di Kabupaten Mempawah Kalimantan Barat. Dalam Perpres tersebut percepatan pembangunan dan pengoperasian Terminal Kijing Pelabuhan Pontianak di Kalimantan Barat dilakukan dalam rangka peningkatan konektivitas, pengembangan infrastruktur kemaritiman, dan pengembangan wilayah di Kalimantan Barat. Terminal kijing terletak di Kabupaten Mempawah yang berlokasi kurang lebih $85 \mathrm{~km}$ dari pusat Kota Pontianak, Terminal Kijing memiliki jarak 44 Nm dari TPK Dwikora, berikut lokasi antara TPK Dwikora yang terletak di pusat Kota Pontianak dan Terminal Kijing. Kedua Terminal tersebut memiliki jarak sebesar $48 \mathrm{Nm}$, dengan adanya pembangunan Terminal Kijing, maka akan menimbulkan adanya dampak yang terjadi yaitu; berubahnya biaya transportasi muatan dan perlu atau tidaknya rencana pengembangan fasilitas (rencana pendalaman alur) di Terminal Peti Kemas (TPK) Dwikora yang menjadi terminal eksisting. Penelitian ini bertujuan untuk menganalisis dampak tersebut berdasarkan biaya transportasi.

\section{METODOLOGI PENELITIAN}

\section{A. Identifikasi Masalah}

Permasalahan yang timbul dalam kasus pada Penelitian ini adalah dengan adanya pembangunan Terminal Kijing akan berdampak pada Terminal Peti Kemas (TPK) Dwikora (Terminal Eksisting) khususnya pada rencana pengembangan fasilitas di TPK Dwikora (pendalaman alur) yang telah direncanakan, karena dengan adanya pembangunan tersebut terdapat kemungkinan tidak lagi diperlukannya pendalaman alur. Selain itu pembangunan Terminal Kijing berakibat pada berubahnya biaya transportasi muatan karena sebelumnya muatan tersebut dikirim melalui TPK Dwikora.

\section{B. Pengumpulan Data}

Pada tahap ini dilakukan pengumpulan data secara primer juga sekunder, pada pengumpulan data secara primer data diperoleh dari berbagai macam sumber sesuai dengan data yang dibutuhkan, seperti: 
1. Muatan pada wilayah industri pada Kalimantan Barat didapatkan dari Kementerian Perindustrian [2].

2. Kondisi eksisting pada TPK Dwikora, didapatkan dari data yang ada di Terminal tersebut, data yang diperlukan yaitu data kunjungan kapal, data muatan, data tujuan muatan, tarif jasa pelayanan kapal, tarif jasa pelayanan muatan, tarif penumpukan muatan, arus muatan pelabuhan, fasilitas pelabuhan.

3. Rencana pengembangan TPK Dwikora dan pembangunan Terminal Kijing

\section{Analisis Kondisi Saat Ini}

Langkah selanjutnya adalah menganalisis kondisi saat ini, yaitu; TPK Dwikora sebelum adanya pembangunan Terminal Kijing (Kapasitas pelabuhan, fasilitas pelabuhan, frekuensi kedatangan kapal, lalu lintas laut, arus muatan, wilayah industri, rute pelayaran, tarif pelabuhan, kinerja pelabuhan (BCH, BOR, dan YOR).

\section{Analisis Pendalaman Alur dan Biaya Transportasi}

Setelah mengetahui kondisi saat ini, selanjutnya menghitung besar biaya yang diperlukan untuk melakukan pendalaman alur pelayaran. Selanjutnya melakukan analisis biaya transportasi barang dari hinterland menuju TPK Dwikora dan dari hinterland menuju Terminal Kijing.

\section{E. Analisis Dampak Pembangunan Terminal Kijing}

Selanjutnya menganalisis dampak pembangunan Terminal Kijing terhadap biaya transportasi muatan, serta terhadap kinerja TPK Dwikora.

\section{F. Kesimpulan}

Setelah dilakukan analisis maka akan didapatkan hasil serta kesimpulan yang telah dilakukan dengan maksud memberikan saran untuk penelitian selanjutnya.

\section{KONSEP DAN URAIAN PENELITIAN}

\section{A. Konsep Pengerukan Alur Pelayaran}

Pengerukan adalah pekerjaan mengambil tanah di dasar laut atau dasar sungai dari perairan laut atau sungai. Tujuan dari dilakukannya pengerukan yaitu; membuat alur dan atau kolam baru, memelihara alur dan atau kolam eksisting, serta pengerukan untuk pembangunan struktur pelabuhan, seperti dermaga (slope protection), breakwater, graving dry dock, slipway, dan bahan urugan/reklansasi.

\section{B. Konsep Biaya Transportasi Laut}

Pada dasarnya biaya transportasi laut terbagi kedalam empat kategori utama, yaitu; biaya modal (capital cost), biaya operasional (operational cost), biaya pelayaran (voyage cost), dan biaya bongkar muat (cargo handling cost) [3]. Pada penelitian ini biaya modal dan operasional diwakili oleh biaya sewa kapal atau yang biasa disebut dengan Time Charter Hire Kapal. Berikut penjelasan dari Time Charter Hire Kapal, biaya pelayaran, serta biaya bongkar muat:

\section{Time Charter Hire}

Time Charter Hire memiliki komponen yaitu biaya operasional, biaya pemeliharaan, dan biaya modal. Time Charter Hire yang digunakan merupakan data yang didapatkan dari informasi mengenai besar harga sewa kapal yang ada di Indonesia.

2. Biaya Pelayaran (Voyage Cost)

Biaya pelayaran atau voyage cost adalah variabel yang dikeluarkan oleh kapal untuk kebutuhan selama perjalanan. Komponen biaya pelayaran yaitu biaya kebutuhan bahan bakar serta biaya penanganan kapal di pelabuhan asal serta pelabuhan tujuan.

\section{Biaya Bongkar/Muat (Cargo Handling Cost)}

Biaya bongkar muat (Cargo Handling Cost) adalah biaya untuk proses pemindahan muatan dari kapal ke pelabuhan baik di pelabuhan asal ataupun pelabuhan tujuan. Biaya ini dipengaruhi oleh jenis muatan dan alat bongkar muat yang digunakan. Biaya ini meliputi biaya stevedoring dan cargodoring.

\section{Konsep Biaya Transportasi Darat}

Terdapat 9 komponen dalam biaya transportasi darat, dalam penelitian ini transportasi darat yang dimaksud adalah transportasi pengiriman dengan menggunakan truk. 9 komponen tersebut adalah biaya bahan bakar minyak (BBM), biaya operasional driver (toll, parkir, um, honor, mel), biaya maintenance, biaya tire atau ban, biaya depresiasi, biaya bunga investasi, biaya legal \& liaisons, biaya over head, profit atau keuntungan perusahaan. Pada penelitian ini penulis menggunakan metode rasio biaya bbm terhadap tarif. Dalam metode ini disepakati terlebih dahulu prosentase biaya BBM terhadap tarif, apakah 25\%, 30\% atau 35\% [4]. Dalam penelitian ini prosentase yang digunakan adalah $27 \%$.

\section{Utilitas Pelabuhan}

Kinerja utilitas adalah kinerja yang dihubungkan dengan penggunaan fasilitas dermaga, lapangan penumpukan dan peralatan bongkar muat yang meliputi:

- Berth Working Time (BWT), merupakan waktu untuk kegiatan bongkar muat selama kapal berada di dermaga. Cakupan kegiatan ini adalah dengan melihat dan mengamati kesiapan peralatan bongkar muat dan produktivitas peralatan bongkar muat di dermaga. Kesiapan operasi peralatan adalah perbandingan antara jumlah peralatan yang siap untuk dioperasikan dengan jumlah peralatan yang tersedia dalam periode waktu tertentu.

- Berth Occupancy Ratio (BOR), merupakan rasio penggunaan dermaga dan memberikan informasi mengenai seberapa padat arus kapal yang tambat dan melakukan kegiatan bongkar muat di dermaga. Untuk perhitungan tingkat pemakaian dermaga/tambatan untuk beberapa tambatan dilakukan dengan menghitung tingkat pemakaian tambatan didasarkan pada panjang kapal (Length Over All = LOA) ditambah $10 \%$ dari LOA Kapal sebagai faktor pengamanan muka-belakang [5], sehingga perhitungan pada persamaan berikut:

$$
B O R=\frac{\sum((\text { LOA }+ \text { Allowance }) \times \text { waktutambat })}{\sum \text { tambatan } \times 24 \times 365} \times 100 \%
$$

- Yard Occupation Ratio (YOR), merupakan kinerja lapangan penumpukan yang merupakan perbandingan antara 
penggunaan lapangan penumpukan berdasarkan lamanya peti kemas mendiami lapangan penumpukan dengan kapasitas lapangan penumpukan yang tersedia [6].

$$
Y O R=\frac{\text { ArusMuatan }}{\text { KapasitasCY }} \times 100 \%
$$

\section{E. Metode Regresi Linier}

Metode regresi linier merupakan salah satu jenis dari metode peramalan arus muatan serta beberapa hal lainnya seperti peramalan jumah kapal yang akan datang. Peramalan dilakukan dengan menggunakan metode kuantitatif. Metode kuantitatif digunakan apabila terdapat informasi masa lalu dalam bentuk kuantitas dan mengasumsikan bahwa pola data masa lalu digunakan untuk meramalkan apa yang akan terjadi di masa mendatang. Terdapat dua metode kuantitatif, yaitu metode time series dan metode kausal atau korelasi. Metode time series didasarkan pada nilai suatu variabel masa lalu dan bertujuan untuk menemukan pola dari rangkaian masa lalu untuk kemudian diekstrapolasikan pada masa mendatang. Metode kausal atau korelasi meramalkan suatu variabel berdasarkan hubungannya dengan variabel lain yang diperkirakan mempengaruhi, termasuk dalam metode ini adalah analisis regresi.

\section{ANALISIS DAN PEMBAHASAN}

\section{A. Analisis Pendalaman Alur Pelayaran}

Saat ini alur pelayaran Pelabuhan Pontianak memiliki kedalaman tidak lebih dari 5 meter. Dengan kondisi alur tersebut, maka kapal yang dapat memasuki area pelabuhan terbatas. Data historis yang ada menyebutkan pada tahun 2017 kapal dengan sarat terbesar yang datang memiliki sarat 6.2 meter dengan load factor $74 \%$.

Pada alur pelayaran tersebut terjadi pengendapan (sedimentasi) secara terus menerus setiap tahunnya. Berdasarkan pada jurnal yang berjudul "Laju Sedimentasi Menggunakan Metode Isotop di Muara Jungkat Pontianak Kalimantan Barat") [7] menyebutkan bahwa laju sedimentasi di muara Jungkat yang merupakan wilayah dari alur pelayaran adalah sebesar 2,1093 cm/tahun. Dengan adanya pendangkalan yang tersebut menyebabkan kapal dengan draft yang besar memiliki resiko kandas terutama jika air sedang surut. Dalam upaya untuk membuat kapal dengan sarat lebih dari 5 meter dapat menggunakan kapasitasnya dengan maksimal dan membuat kapal-kapal tersebut dengan mudah memasuki wilayah perairan pelabuhan, maka perlu dilakukan pendalaman pada alur pelayaran pelabuhan. Dalam pelaksanaan pendalaman alur tentunya membutuhkan biaya, berikut langkah-langkah yang dilakukan dalam menentukan biaya tersebut:

1. Menganalisis Volume Pengerukan

Dalam mengetahui nilai volume pengerukan maka dibutuhkan mengetahui kedalaman yang dibutuhkan. Kedalaman yang dibutuhkan sesuai dengan Rencana Induk Pelabuhan Pontianak yaitu akan dilakukan pendalaman sampai dengan kedalaman 7 meter. Kemudian dilakukan penentuan panjang alur yang dikeruk sesuai dengan daerah perairan yang dangkal. Pada gambar diatas dapat diketahui panjang wilayah perairan yang dikeruk daerah dangkal yang terdapat pada titik buoy 1 sampai pada buoy 10 dengan jumlah panjang 156 meter atau 15.6 kilometer. Setelah itu menentukan lebar alur pelayaran, sesuai dengan kondisi saat ini yaitu 60 meter.

Dengan mengetahui kedalaman, panjang, dan luas area pengerukan maka didapatkan volume tanah yang akan dikeruk untuk capital dredging sebesar 3,327,180 $\mathrm{m}^{3}$, sedangkan untuk maintenance dredging sebesar 198,819 $\mathrm{m}^{3}$ dengan asumsi sedimentasi sebesar $2,1093 \mathrm{~cm} /$ tahun.

Biaya pengerukan pada setiap $\mathrm{m}^{3}$ nya yaitu sebesar $\mathrm{Rp}$ 68,472 . Penulis mengasumsikan periode proyeksi dari pengerukan alur ini adalah 50 tahun. Sehingga perhitungan biaya investasi dihitung sampe 50 tahun kedepan dengan asumsi kenaikan inflasi $4.5 \%$ serta pajak yang harus dikeluarkan sebesar 10\%. Maka biaya capital dredging yaitu sebesar Rp 227 Miliar dan biaya maintenance dredging tiap 10 tahun yaitu Rp 13.6 Miliar. Jumlah untuk biaya pendalama alur adalah 709 miliar rupiah.

Pendalaman alur pelayaran ini akan berakibat pada bertambahnya biaya transportasi. Biaya pendalaman alur ini akan dibebankan pada tiap TEU peti kemas yang diangkut pada kapal datang. Untuk mendapatkan berapa biaya yang akan dibebankan didapatkan dari pembagian total biaya pengerukan dengan proyeksi jumlah arus muatan yang akan datang di pelabuhan, jumlah arus muatan (TEUs) yang diproyeksikan akan datang 50 tahun kedepan adalah $32,646,060$ sehingga didapatkan nilai Rp 21,720 per TEU yang dibebankan pada setiap peti kemas.

\section{B. Analisis Lalu Lintas Laut Terminal Peti kemas Dwikora}

Selanjutnya dilakukan analisis terhadap kondisi lalu lintas laut pada Terminal Peti Kemas (TPK) Dwikora yang menjadi subjek Penelitian saat ini. Kondisi lalu lintas laut merupakan gambaran mengenai kapal-kapal yang melalui TPK Dwikora pada saat ini. Kapal yang datang di TPK Dwikora adalah kapal dengan memiliki berbagai macam ukuran, dalam menganalisis kondisi eksisting lalu lintas di TPK Dwikora penulis mengelompokkan kapal yang datang berdasarkan dari sarat yang dimiliki oleh kapal-kapal tersebut karena fokusan dari penulis adalah mengenai kedalaman di perairan pelayaran pelabuhan. Pengelompokan berdasarkan sarat kapal adalah sebagai berikut:

Tabel 1

Pengelompokan Berdasarkan Sarat Kapal Peti Kemas

\begin{tabular}{ccc}
\hline \hline Cluster & $\begin{array}{c}\text { Range Sarat Kapal } \\
\text { (meter) }\end{array}$ & $\begin{array}{c}\text { Range Kapasitas Kapal } \\
\text { (TEUs) }\end{array}$ \\
\hline Cluster 1 & $3.0-4$ & $<97$ \\
Cluster 2 & $4.1-5$ & $114-267$ \\
Cluster 3 & $5.1-6$ & $284-437$ \\
Cluster 4 & $6.1-7$ & $454-556$ \\
Cluster 5 & $7.1-8$ & $624-777$ \\
Cluster 6 & $8.1-9$ & $794-947$ \\
\hline \hline
\end{tabular}

Pada tahun 2017 terdapat 5 daerah rute asal dan tujuan kapal. Daerah tersebut yaitu Jakarta, Surabaya, Semarang, Pekanbaru, serta Singapura. Berikut diagram untuk mengetahui kondisi tersebut: 


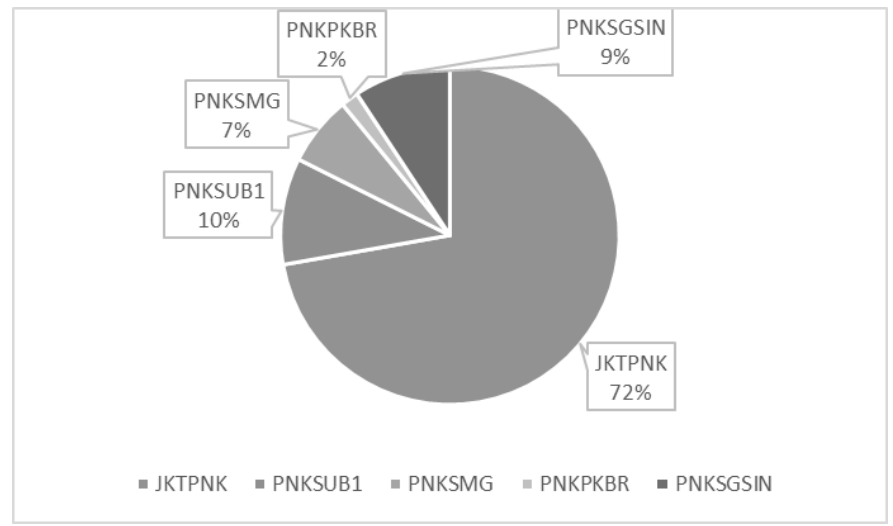

Gambar 1. Diagram asal/tujuan kapal yang datang.

Keterangan inisial yang ada pada diagram diatas yaitu merupakan rute JKTPNK (Jakarta - Pontianak), PNKSUB1 (Pontianak - Surabaya), (PNKSMG (Pontianak - Semarang), PNKPKBR (Pontianak - Pekanbaru), serta PNKSGSIN (Pontianak - Singapura). Diagram diatas menunjukkan bahwa kapal yang bersandar dan melakukan bongkar/muat di TPK Dwikora didominasi oleh kapal dari/menuju Jakarta dengan prosentase sebesar $72 \%$ dengan jumlah dari kedatangan kapal/ship call di pelabuhan yaitu $540 \mathrm{kapal}$. Berdasarkan pada prosentase diatas maka kapal dari/menuju jakarta adalah sebanyak 390 kali kedatangan. Dengan adanya rute Jakarta yang mendominasi maka pada Penelitian ini penulis hanya akan membahas mengenai rute Pontianak - Jakarta. Maka pada bahasan selanjutnya rute yang dimaksud adalah Pontianak - Jakarta. Lalu lintas laut dengan rute kapal Pontianak - Jakarta dapat dilihat pada tabel dibawah ini:

Tabel 2.

Lalu Lintas Laut Rute Pontianak - Jakarta

\begin{tabular}{lcccc}
\hline \multicolumn{1}{c}{ Item } & Satuan & Cluster 2 & Cluster 3 & Cluster 4 \\
\hline Range Kapal (Sarat) & Meter & $4.1-5$ & $5.1-6$ & $6.1-7$ \\
$\begin{array}{l}\text { Jumlah Kedatangan } \\
\text { Kapal }\end{array}$ & $\begin{array}{c}\text { Kapungan } \\
\text { Kapal }\end{array}$ & 113 & 251 & 23 \\
Range DWT & Ton & $5300-$ & $4174-$ & 8125 \\
Jumlah Muatan & TEUs & 27,003 & 71,439 & 6,464 \\
$\begin{array}{l}\text { Bongkar } \\
\text { Jumlah Muatan }\end{array}$ & TEUs & 28,944 & 69,104 & 5,443 \\
$\begin{array}{l}\text { Muat } \\
\text { Prosentase Muatan }\end{array}$ & Persen & $28 \%$ & $67 \%$ & $5 \%$ \\
$\begin{array}{l}\text { Load factor } \\
\text { Terbesar }\end{array}$ & Persen & $88 \%$ & $81 \%$ & $74 \%$ \\
\hline \hline
\end{tabular}

Untuk dapat melakukan analisis perhitungan pada Penelitian ini diperlukan ukuran kapal dari masing-masing cluster kapal. Ukuran kapal yang dijadikan sebagai acuan dari masingmasing cluster adalah sarat kapal. Sarat kapal yang digunakan pada masing-masing cluster kapal yaitu sarat terbesar di setiap cluster kapal. Pada cluster 2 sarat kapal yang digunakan yaitu kapal dengan sarat 5 meter, cluster 3 memiliki sarat 6 meter, dan cluster 4 memiliki sarat 6.2 meter. Sarat tersebut didapat dari sarat yang dimiliki oleh kapal yang datang di pelabuhan. Untuk menentukan ukuran lainnya (LOA, DWT, B, GT, Kapasitas, Kecepatan, dan Daya Mesin) pada masing-masing cluster didapatkan dengan menggunakan metode regresi linier. Nilai regresi didapatkan dari database kapal peti kemas.
Berikut ukuran kapal yang digunakan dalam melakukan analisis perhitungan biaya transportasi laut:

Tabel 3.

Ukuran Utama Kapal yang Digunakan

\begin{tabular}{lcccc}
\hline \multicolumn{1}{c}{ Item } & Satuan & Cluster 2 & Cluster 3 & Cluster 4 \\
\hline Range Kapal (Sarat) & Meter & $4.1-5$ & $5.1-6$ & $6.1-7$ \\
Sarat Terbesar & Meter & 5 & 6 & 6.2 \\
DWT & Ton & 3,511 & 6,205 & 6,744 \\
Panjang Kapal (LOA) & Meter & 90 & 105 & 109 \\
Lebar Kapal (B) & Meter & 14 & 15.8 & 16.1 \\
GT & & 2,509 & 4,627 & 5,050 \\
Kapasitas & TEUs & 267 & 437 & 471 \\
Kecepatan Dinas & $V s$ & 9.44 & 10.44 & 10.63 \\
Main Engine (Mesin & $K w$ & 2,720 & 4,464 & 4,813 \\
Utama) & $K w$ & 905 & 1,203 & 1,263 \\
Auxiliary Engine (Mesin & $K w$ Bantu) & & & \\
Bantu & & &
\end{tabular}

\section{Analisis Perhitungan Biaya Transportasi Laut}

Sebelum membahas mengenai analisis biaya transportasi laut, perlu diketahui bahwa penulis akan menuliskan hasil dari biaya transportasi laut ini dengan masing-masing cluster kapal dengan 4 kondisi, yaitu:

1. Skenario 1, merupakan kondisi eksisting/saat ini. Load factor kapal yang digunakan pada kapal cluster 2 adalah $88 \%$, cluster 3 adalah $81 \%$, cluster 4 adalah $74 \%$.

2. Skenario 2, merupakan kondisi jika dilakukan pengerukan pada alur masuk pelayaran di pelabuhan. Load factor kapal yang digunakan pada hitungan ini yaitu 100\% karena tidak terbatas sarat.

3. Skenario 3, merupakan kondisi ketika kapal melalui Terminal Kijing. Load factor kapal yang digunakan pada hitungan ini yaitu 100\% karena tidak terbatas sarat dimana kedalaman di Terminal Kijing memiliki kedalaman sampai 12 mLWS.

4. Skenario 4, merupakan gabungan dari skenario 2 dan 3 namun pada kedua skenario tersebut terjadi pembagian hinterland hinterland.

Penulis melakukan perhitungan biaya transportasi laut dengan 4 skenario diatas dengan 3 cluster kapal yaitu cluster 2 , cluster 3, dan cluster 4 yang meliputi biaya sewa kapal, biaya perjalanan dan biaya bongkar muat. Berikut hasil dari perhitungan tersebut:

Tabel 4.

Biaya Transportasi Laut (Jt-Rp/TEU)

\begin{tabular}{cccc}
\hline \hline Cluster Kapal & Skenario 1 & Skenario 2 & Skenario 3 \\
\hline Cluster 2 & 8.6 & 8.0 & 8.4 \\
Cluster 3 & 8.0 & 7.2 & 7.4 \\
Cluster 4 & 8.4 & 7.0 & 7.0 \\
\hline \hline
\end{tabular}

\section{Analisis Perhitungan Biaya Transportasi Darat}

Pada analisis biaya transportasi darat dihitung kebutuhan bahan bakar untuk dapat melakukan pengiriman muatan, pengiriman dilakukan dengan menggunakan truk dengan kapasitas 25 ton sehingga dapat mengangkut peti kemas dengan muatan di dalamnya. Penulis mengasumsikan bahwa truk yang digunakan adalah sama dan pada truk memiliki rasio bahan bakar minyak $2.5 \mathrm{~km}$ per liter yang artinya setiap truk menempuh jarak $2.5 \mathrm{~km}$ dengan 1 liter BBM. Pada perhitungan ini menggunakan asumsi harga BBM solar sebesar Rp 8,700/liter. 
Terdapat 11 Kabupaten yang menjadi hinterland pada perhitungan ini, yaitu Kabupaten Sambas, Bengkayang, Landak, Pontianak, Sanggau, Ketapang, Sintang, Kapuas Hulu, Sekadau, Kubu Raya, Kota Pontianak. Pada masing-masing hinterland yang ada memiliki jarak masing-masing ke Terminal Kijing dan TPK Dwikora. Jarak ini akan menjadi komponen penting dalam analisis biaya transportasi darat karena berkaitan erat dengan penggunaan bahan bakar serta waktu perjalanan. Berikut masing-masing jarak hinterland ke TPK Dwikora dan Terminal Kijing:

Tabel 5.

Jarak dan Waktu

\begin{tabular}{|c|c|c|c|c|}
\hline \multirow[b]{2}{*}{ Kabupaten } & \multicolumn{2}{|c|}{ TPK Dwikora } & \multicolumn{2}{|c|}{ Terminal Kijing } \\
\hline & $\begin{array}{c}\text { Jarak } \\
(\mathrm{km})\end{array}$ & $\begin{array}{c}\text { Waktu } \\
\text { Tempuh } \\
\text { (Jam) }\end{array}$ & $\begin{array}{c}\text { Jarak } \\
(\mathrm{km})\end{array}$ & $\begin{array}{c}\text { Waktu } \\
\text { Tempuh } \\
\text { (Jam) }\end{array}$ \\
\hline Sambas & 231 & 25.67 & 137 & 15.22 \\
\hline Bengkayang & 215 & 23.89 & 154 & 17.11 \\
\hline Landak & 138 & 15.33 & 134 & 14.89 \\
\hline Pontianak & 79 & 8.78 & 42 & 4.67 \\
\hline Sanggau & 175 & 19.44 & 234 & 26.00 \\
\hline Ketapang & 357 & 39.67 & 439 & 48.78 \\
\hline Sintang & 311 & 34.56 & 370 & 41.11 \\
\hline Kapuas Hulu & 575 & 63.89 & 633 & 70.33 \\
\hline Sekadau & 253 & 28.11 & 312 & 34.67 \\
\hline Kubu Raya & 53 & 5.89 & 141 & 15.67 \\
\hline Kota Pontianak & 2.7 & 0.30 & 92 & 10.22 \\
\hline
\end{tabular}

Pada perhitungan ini untuk mendapatkan tarif pengiriman transportasi darat penulis menggunakan asumsi besaran rasio biaya bahan bakar terhadap tarif yaitu sebesar 2.75 . Penulis membagikan biaya untuk bahan bakar dengan persenan tersebut sehingga menghasilkan tarif untuk pengiriman peti kemas dengan satuan Rp/TEU sebagai berikut:

Tabel 6.

Biaya Transportasi Darat

\begin{tabular}{lcc}
\hline \multirow{2}{*}{ Kabupaten } & \multicolumn{2}{c}{ Biaya (Rp/TEU) } \\
\cline { 2 - 3 } & TPK Dwikora & Terminal Kijing \\
\hline Sambas & $2,210,670$ & $1,311,090$ \\
Bengkayang & $2,057,550$ & $1,473,780$ \\
Landak & $1,320,660$ & $1,282,380$ \\
Pontianak & 756,030 & 401,940 \\
Sanggau & $1,674,750$ & $2,239,380$ \\
Ketapang & $3,416,490$ & $4,201,230$ \\
Sintang & $2,976,270$ & $3,540,900$ \\
Kapuas Hulu & $5,502,750$ & $6,057,810$ \\
Sekadau & $2,421,210$ & $2,985,840$ \\
Kubu Raya & 507,210 & $1,349,370$ \\
Kota Pontianak & 25,839 & 880,440 \\
\hline \hline
\end{tabular}

Berdasarkan pada tabel diatas, diperoleh biaya stauan untuk mengirimkan satu peti kemas dari masing-masing wilayah Kabupaten ke TPK Dwikora dan Terminal Kijing. Terdapat beberapa daerah yang memiliki nilai lebih rendah jika melakukan perjalanan ke TPK Dwikora yaitu Kabupaten Sanggau, Ketapang, Sintang, Kapuas Hulu, Sekadau, Kubu Raya, dan Kota Pontianak. Sedangkan Kabupaten Sambas, Bengkayang, Landak, dan Pontianak lebih murah menuju Terminal Kijing.

\section{E. Analisis Total Biaya Transportasi Muatan}

Total biaya transportasi merupakan pertambahan dari total biaya transportasi laut dengan total biaya transportasi darat.
Dengan adanya prosentase produksi pada masing-masing Kabupaten di wilayah Kalimantan Barat, penulis mengasumsikan bahwa muatan yang diambil dari data muat dari pelabuhan merupakan jumlah produksi di Kalimantan Barat yang dikirim ke Jakarta (Ekspor). Dengan mengalikan prosentase pada masing-masing daerah dengan jumlah produksi dalam TEUs yang ada, maka didapatkan jumlah muatan yang akan dikirimkan pada masing-masing hinterland. Berikut prosentase pembagian muatan pada masing-masing Kabupaten:

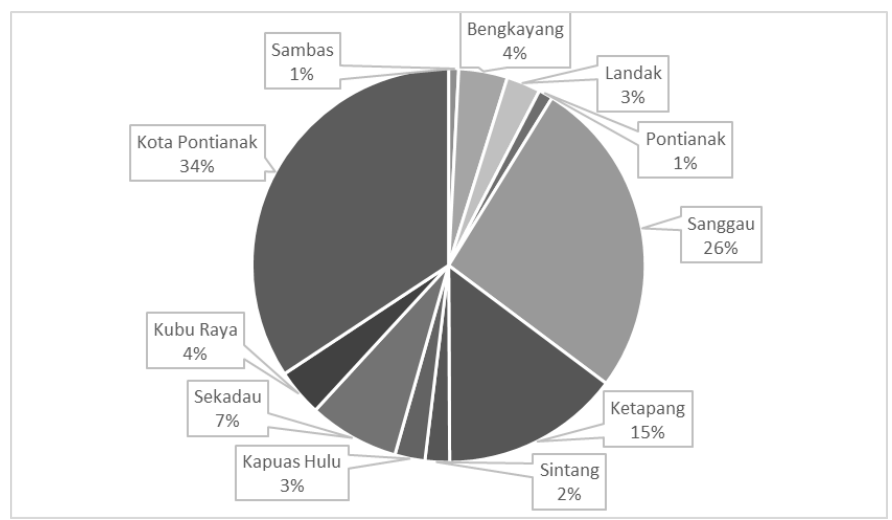

Gambar 2. Prosentase Muatan di Hinterland.

Berdasarkan pada gambar diatas, Kota Pontianak memiliki prosentase terbesar. Setelah mendapatkan prosentase diatas, maka dilakukan pembagian muatan pada setiap cluster kapal. Pembagian dilakukan berdasarkan data historis yang didapatkan penulis dari TPK Dwikora. Berikut pembagian muatan pada masing-masing cluster kapal:

Tabel 7.

Pembagian Muatan Masing-masing Cluster Kapal Peti Kemas pada Skenario 1 , dan 2

\begin{tabular}{lccc}
\hline \hline \multicolumn{1}{c}{ Keterangan } & Cluster 2 & Cluster 3 & Cluster 4 \\
\hline Prosentase & $30 \%$ & $64 \%$ & $6 \%$ \\
Jumlah Muatan (TEUs/Tahun) & 30,782 & 66,606 & 6,103 \\
\hline \hline
\end{tabular}
Tabel 8.

Pembagian Muatan Masing-masing Cluster Kapal Peti Kemas pada Skenario

\begin{tabular}{lccc}
\multicolumn{4}{c}{3} \\
\hline \multicolumn{1}{c}{ Keterangan } & Cluster 2 & Cluster 3 & Cluster 4 \\
\hline Prosentase & $17 \%$ & $33 \%$ & $50 \%$ \\
Jumlah Muatan (TEUs/Tahun) & $17,593.47$ & $34,152.03$ & $51,745.50$ \\
\hline \hline
\end{tabular}

Dengan diketahuinya jumlah muatan pada masing-masing hinterland dengan menggunakan prosentase pembagian diatas, maka dapat diketahui total biaya transportasi dalam satu tahun untuk mengirimkan keseluruhan muatan tersebut. Berikut rekapitulasi dari total biaya transportasi disetiap cluster dengan 3 skenario pada masing-masing hinterland:

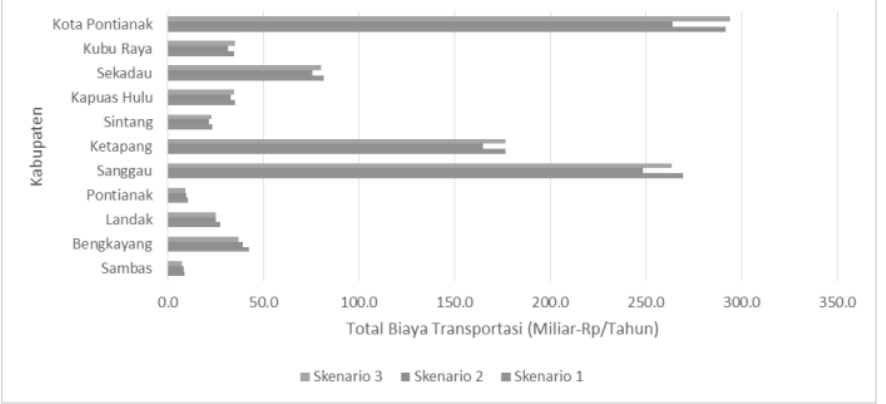

Gambar 3. Diagram Total biaya Transportasi Masing-masing Hinterland. 
Berdasarkan pada diagram diatas, terdapat 4 Kabupaten yaitu Kabupaten Sambas, Bengkayang, Landak, dan Pontianak yang memiliki biaya transportasi yang lebih rendah jika mengirimkan muatannya melalui Terminal Kijing (skenario 3). Sedangkan 7 Kabupaten lainnya yaitu Sanggau, Ketapang, Sintang, Kapuas Hulu, Sekadau, Kubu Raya, dan Kota Pontianak lebih murah jika mengirimkan muatan melalui TPK Dwikora (skenario 2). Hal ini diakibatkan karena adanya perbedaan jarak pada masing-masing Kabupaten, perbandingan biaya tersebut cenderung lebih murah jika jarak antara Kabupaten dengan terminal lebih dekat, meskipun pada analisis biaya transportasi laut menyebutkan bahwa biaya transportasi laut yang paling murah adalah jika kapal melalui Terminal Kijing. Dengan demikian, hinterland Terminal Kijing adalah Kabupaten Sambas, Bengkayang. Landak dan Pontianak. Sedangkan hinterland TPK Dwikora adalah Kabupaten Sanggau, Ketapang, Sintang, Kapuas Hulu, Sekadau, Kubu Raya, dan Kota Pontianak. Berikut gambar dari hinterland Terminal Kijing dan TPK Dwikora:

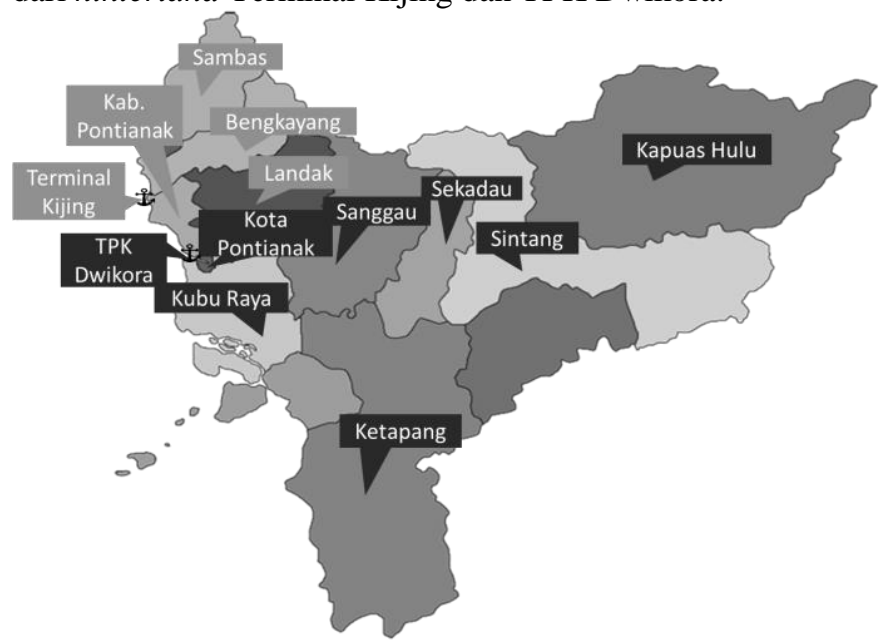

Gambar 4. Peta Hinterland TPK Dwikora dan Terminal Kijing.

Selanjutnya penulis melakukan pengembangan pada skenario yang digunakan yaitu pada skenario 4 . Kondisi pada skenario 4 merupakan gabungan dari skenario 2 dan 3 namun pada kedua skenario tersebut terjadi perpindahan hinterland, pada kondisi ini hinterland Terminal Kijing mengirimkan muatannya melalui Terminal Kijing, dan begitupula untuk Terminal Dwikora. Berikut total biaya transportasi dengan menggunakan seluruh skenario yang ada:

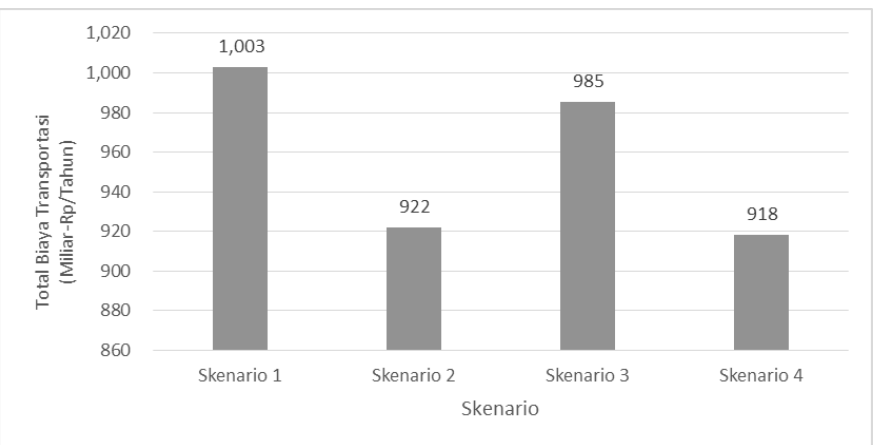

Gambar 5. Diagram Total Biaya Transportasi.
Berdasarkan pada diagram diatas, biaya transportasi paling rendah ada pada skenario 4 dengan prosentase penurunan biaya sebesar 8\% dari skenario 1 (kondisi eksisting).

\section{F. Analisis Dampak Pembangunan Terminal Kijing}

\section{1) Dampak Terminal Kijing terhadap Biaya Transportasi}

Berdasarkan pada analisis yang dilakukan terdapat 4 skenario untuk mengetahui dampak adanya pembangunan Terminal Kijing terhadap biaya transportasi. Pada skenario 1 merupakan kondisi eksisting yang menjadi pembanding untuk ke-empat skenario lainnya. Berikut tabel mengenai perbedaan dari masing-masing skenario:

\begin{tabular}{|c|c|c|c|c|}
\hline Item & $\begin{array}{c}\text { Skenario } \\
1 \\
\end{array}$ & $\begin{array}{c}\text { Skenario } \\
2 \\
\end{array}$ & $\begin{array}{c}\text { Skenario } \\
3 \\
\end{array}$ & $\begin{array}{c}\text { Skenaric } \\
4\end{array}$ \\
\hline \multicolumn{5}{|l|}{ TPK Dwikora } \\
\hline Eksisting & $\sqrt{ }$ & & & \\
\hline Pendalaman Alur & & $\sqrt{ }$ & & $\sqrt{ }$ \\
\hline Terminal Kijing & & & $\sqrt{ }$ & 1 \\
\hline \multicolumn{5}{|l|}{ Hinterland } \\
\hline Sambas & $\sqrt{ }$ & $\sqrt{ }$ & $\sqrt{ }$ & 1 \\
\hline Bengkayang & $\sqrt{ }$ & $\sqrt{ }$ & $\sqrt{ }$ & 1 \\
\hline Landak & $\sqrt{ }$ & $\sqrt{ }$ & $\sqrt{ }$ & 1 \\
\hline Pontianak & $\sqrt{ }$ & $\sqrt{ }$ & $\sqrt{ }$ & 1 \\
\hline Sanggau & $\sqrt{ }$ & $\sqrt{ }$ & $\sqrt{ }$ & $\sqrt{ }$ \\
\hline Ketapang & $\sqrt{ }$ & $\sqrt{ }$ & $\sqrt{ }$ & $\sqrt{ }$ \\
\hline Sintang & $\sqrt{ }$ & $\sqrt{ }$ & $\sqrt{ }$ & $\sqrt{ }$ \\
\hline Kapuas Hulu & $\sqrt{ }$ & $\sqrt{ }$ & $\sqrt{ }$ & $\sqrt{ }$ \\
\hline Sekadau & $\sqrt{ }$ & $\sqrt{ }$ & $\sqrt{ }$ & $\sqrt{ }$ \\
\hline Kubu Raya & $\sqrt{ }$ & $\sqrt{ }$ & $\sqrt{ }$ & $\sqrt{ }$ \\
\hline Kota Pontianak & $\sqrt{ }$ & $\sqrt{ }$ & $\sqrt{ }$ & $\sqrt{ }$ \\
\hline
\end{tabular}

Dengan adanya perbedaan pada masing-masing skenario pada tabel diatas, berikut kesimpulan dari analisis perhitungan yang telah dilakukan:

1.Perbandingan antara skenario 2 dan 1 yaitu skenario 2 memiliki nilai yang lebih rendah dengan perbedaan nilai sebesar Rp 81 Miliar dengan prosentase penurunan $8.1 \%$. Penurunan ini disebabkan karena pada skenario 2 kapal yang datang dapat memaksimalkan muatan angkutnya sampai dengan kapasitas maksimal kapal, hal tersebut terjadi karena pelabuhan melakukan pendalaman alur sehingga tidak ada batas kedalaman untuk kapal yang datang.

2.Perbandingan antara skenario 3 dan 1 yaitu skenario 3 memiliki nilai yang lebih rendah dengan perbedaan nilai sebesar Rp 17 Miliar dengan prosentase penurunan $2 \%$. Penurunan ini disebabkan karena kapal yang datang dapat memaksimalkan muatannya karena di Terminal Kijing memiliki kedalaman lebih dari -5 mLWS.

3.Perbandingan antara skenario 4 dan 1 yaitu skenario 4 memiliki nilai yang lebih rendah dengan perbedaan nilai sebesar Rp 85 Miliar dengan prosentase penurunan $8.4 \%$. Penurunan ini disebabkan karena dari 11 Kabupaten yang ada dengan 4 Kabupaten yang menjadi hinterland Terminal Kijing mengirimkan muatannya melalui Terminal Kiing dan 7 Kabupaten hinterland TPK Dwikora mengirimkan muatannya melalui TPK Dwikora. Juga pada skenario 4 ini biaya transportasi laut memlaui TPK Dwikora yang digunakan adalah kondisi dimana TPK Dwikora melakukan pendalaman (skenario 2). 
4.Pada penjelasan pada poin 1 sampai 3 dapat diambil kesimpulan bahwa biaya paling murah adalah skenario 4 .

2) Dampak Terminal Kijing terhadap Rencana Pengembangan TPK Dwikora

Berdasarkan pada analisis yang telah dilakukan diatas, skenario terbaik adalah skenario 4 dengan kondisi Terminal Kijing dibangun dan pendalaman alur tetap dilakukan. Sehingga adanya Terminal Kijing tidak berdampak terhadap rencana pengembangan TPK Dwikora (rencana pendalaman alur) karena dapat menurunkan biaya transportasi sebesar Rp 83 Miliar dengan prosentase penurunan $7.8 \%$ dari kondisi eksisting.

3) Dampak Terminal Kijing terhadap Arus Muatan dan Kinerja TPK Dwikora

Skenario 4 merupakan skenario terbaik dengan kondisi adanya pembagian muatan berdasarkan hinterland masingmasing Terminal. Sehingga yang awalnya semua wilayah menjadi hinterland TPK Dwikora, pada skenario 4 terjadi pembagian hinterland, hal tersebut membuat adanya pengurangan muatan pada TPK Dwikora. Adanya pengurangan tersebut membuat adanya dampak pada arus muatan serta kinerja di TPK Dwikora. Berikut analisis mengenai hal tersebut:

- Arus Muatan Setelah Pembagian Muatan

Total muatan yang berpindah adalah 9,125 TEUs. Nilai ini merupakan nilai muatan muat, sehingga untuk mendapatkan muatan bongkar dan muat dilakukan perkalian terhadap prosentase bongkar dan muat pada kondisi eksisting. Prosentase bongkar dan muat tersebut adalah 50.3\% untuk muatan bongkar dan $49.7 \%$ untuk muatan muat. Sehingga didapat total muatan bongkar dan muat adalah 18,375 TEUs. Total muatan bongkar dan muat tersebut menjadi nilai arus muatan perpindahan yang akan dikurangkan dengan nilai arus muatan saat ini yang memiliki nilai 244,485 TEUs/tahun. Sehingga didapatkan arus muatan setelah adanya pembagian muatan adalah sebesar 226,110 TEUs/tahun

- Kinerja TPK Dwikora yaitu Berth Occupancy Ratio (BOR) dan Yard Occupancy Ratio (YOR)

Berikut tabel mengenai kondisi sebelum dan sesudah adanya pembagian muatan:

Tabel 10.

Perbandingan Kinerja TPK Dwikora

\begin{tabular}{|c|c|c|}
\hline Item & Eksisting & Setelah Pembagian Muatan \\
\hline Arus Muatan & 244,485 & 226,110 \\
\hline BOR & $53 \%$ & $49.6 \%$ \\
\hline YOR & $54 \%$ & $50.0 \%$ \\
\hline
\end{tabular}

Berdasarkan pada tabel diatas, dengan adanya pembagian muatan menyebabkan penurunan terhadap arus muatan, BOR, dan YOR di TPK Dwikora. Hal ini disebabkan karena dengan menurunnya arus muatan maka berakibat pada berkurangnya jumlah kedatangan kapal dan waktu kapal bersandar di pelabuhan.

\section{G. Hubungan Biaya Transportasi yang Dihemat dengan Investasi Pembangunan Terminal Kijing}

\section{1) Investasi Terminal Kijing}

Penulis melakukan analisis nilai investasi yang dibutuhkan untuk membangun Terminal Kijing khusus pada muatan peti kemas. Komponen dalam investasi yaitu biaya pengadaan yang terdiri dari biaya pembangunan dermaga, trestle, lapangan penumpukan, serta pengadaan peralatan bongkar/muat beserta truk yang dibutuhkan. Dalam melakukan analisis nilai investasi pelabuhan, penulis menggunakan beberapa asumsi untuk mendukung perhitungan, yaitu; tingkat inflasi $4.50 \%$, umur ekonomis pelabuhan 50 tahun, umur ekonomis alat bongkar muat (container crane dan Rail Mounted Gantry Crane) 20 tahun, umur ekonomis truk 10 tahun. Dengan asumsi tersebut, nilai investasi pembangunan Terminal Kijing adalah sebesar Rp 4.9 Triliun. Kemudian penulis menganalisis biaya investasi untuk setiap tahunnya atau melakukan anuitas. Dengan asumsi kenaikan inflasi tiap tahun sebesar $4.5 \%$, maka nilai investasi pada setiap tahunnya adalah sebesar Rp 252 Miliar.

\section{2) Biaya Transportasi yang dihemat/Efisiensi Biaya pada}

\section{Skenario 4}

Biaya yang dapat dihemat pada tahun pertama (2017) adalah sebesar Rp 99 Miliar dengan arus muatan sebesar 244,485 TEUs. Selanjutnya penulis menganalisis besar biaya transportasi yang daat dihemat dalam 50 tahun kedepan dengan menggunakan nilai arus muatan yang memiliki hubungan dengan nilai PDRB Provinsi Kalimantan Barat. Berikut hasil analisis dari biaya yang di hemat dengan nilai arus muatan di Kalimantan Barat selama 50 tahun.

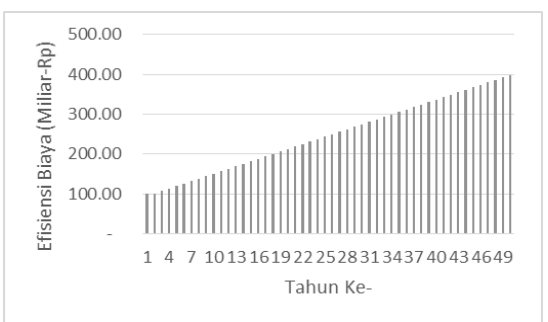

Gambar 6. Diagram Efisiensi Biaya Setiap Tahun.

Berdasarkan pada diagram diatas, jumah dari biaya transportasi yang dapat dihemat selama 50 tahun kedepan adalah sebesar Rp 12 Triliun, dari jumlah tersebut didapatkan anuitas Rp/tahun nya adalah sebesar Rp 623 Miliar.

Tabel 11.

Efisiensi Biaya dengan Investasi Pembangunan Terminal Kijing

\begin{tabular}{lcc}
\hline \hline \multicolumn{1}{c}{ Item } & Satuan & Nilai \\
\hline Investasi & Miliar-Rp/tahun & 252 \\
Efisiensi Biaya & Miliar-Rp/tahun & 623 \\
\hline \hline
\end{tabular}

Berdasarkan pada tabel diatas, dengan membandingkan nilai investasi pembangunan Terminal Kijing sebesar Rp 252 Miliar per tahun dengan nilai biaya transportasi yang dapat dihemat (efisiensi biaya) sebesar Rp 623 Miliar selama 50 tahun, maka nilai investasi pembangunan Terminal Kijing sesuai dengan efisiensi biaya yang ada.

\section{KESIMPULAN}

Berdasarkan hasil analisa dan pembahasan pada Penelitian ini, didapatkan beberapa kesimpulan sebagai berikut:

1. Total biaya transportasi (transportasi darat dan transportasi laut) dalam satu tahun dari Kabupaten Sambas lebih rendah 17\% yaitu Rp 765 Juta, Bengkayang lebih rendah 14\% yaitu Rp 2,454 Juta, Landak lebih rendah 10\% yaitu Rp 132 Juta, 
dan Pontianak lebih rendah 14\% yaitu Rp 438 Juta jika melalui Terminal Kijing daripada jika melalui TPK Dwikora (ada pendalaman alur). Sedangkan 7 Kabupaten lainnya (Sanggau, Ketapang, Sintang, Kapuas Hulu, Sekadau, Kubu Raya, dan Kota Pontianak) memiliki nilai biaya transportasi yang lebih rendah dengan rata-rata selisih biaya sebesar $7 \%$ jika melalui TPK Dwikora.

2.Penentuan hinterland Terminal Kijing dan TPK Dwikora berdasarkan pada kesimpulan poin nomor 1 (satu), yaitu Hinterland untuk Terminal Kijing adalah Kabupaten Sambas, Bengkayang, Landak, dan Pontianak, sedangkan hinterland TPK Dwikora adalah Kabupaten Sanggau, Ketapang, Sintang, Kapuas Hulu, Sekadau, Kubu Raya, serta Kota Pontianak.

3. Berikut hasil analisis biaya transportasi (transportasi darat dan transportasi laut) dalam satu tahun pada setiap skenario:

Skenario 1 (Kondisi Eksisting)

Memiliki total biaya transportasi sebesar Rp 1,003 Miliar

Skenario 2 (Muatan melalui TPK Dwikora melakukan pendalaman alur)

Memiliki total biaya transportasi sebesar Rp 992 Miliar. Perbandingan antara skenario 2 dan 1 yaitu skenario 2 memiliki nilai yang lebih rendah dengan perbedaan nilai sebesar Rp 81 Miliar dengan prosentase penurunan $8.1 \%$

Skenario 3 (Muatan melalui Terminal Kijing)

Memiliki total biaya transportasi sebesar Rp 985 Miliar. Perbandingan antara skenario 3 dan 1 yaitu skenario 3 memiliki nilai yang lebih rendah dengan perbedaan nilai sebesar Rp 17 Miliar dengan prosentase penurunan $2 \%$.
Skenario 4 (terdapat pembagian muatan sesuai dengan hinterland Terminal Kijing dan TPK Dwikora)

Memiliki total biaya transportasi sebesar Rp 918 Miliar. Perbandingan antara skenario 4 dan 1 yaitu skenario 4 memiliki nilai yang lebih rendah dengan perbedaan nilai sebesar Rp 85 Miliar dengan prosentase penurunan $8.4 \%$.

4. Dengan adanya Terminal Kijing dengan nilai investasi sebesar Rp 4.9 Triliun dan pendalaman alur di TPK Dwikora dengan biaya pendalaman sebesar Rp 709 Miliar maka dapat menghemat biaya transportasi (transportasi darat dan transportasi laut) sebesar $8.4 \%$ dari kondisi eksisting.

\section{UCAPAN TERIMA KASIH}

Penulis kepada staf Pelabuhan Indonesia II (Persero) Cabang Pontianak yaitu Pak Edi dan Pak Ripto yang telah membantu penulis dalam proses pengumpulan data dan informasi.

\section{DAFTAR PUSTAKA}

[1] Menteri Perhubungan Republik Indonesia, "Rencana Induk Pelabuhan Pontianak," Jakarta, 2016.

[2] Kementerian Perindustrian Indonesia, "Produksi Kalimantan Barat," Jakarta, 2018.

[3] N. W. Wergeland, Shipping. Netherland, 1997.

[4] S. Purnoto, "Tantangan Dan Strategi Truk Angkutan Barang dalam Menciptakan Keunggulan Bersaing," 2016.

[5] B. Triadmodjo, Perencanaan Pelabuhan. Yogyakarta: Beta Offset, 2010.

[6] D. Lasse, Manajemen Kepelabuhanan, Jakarta: Nika, 2012.

[7] N. Sa'adah, P. Subardjo, and Warsito Atmodjo, "Laju Sedimen Menggunakan Metode Isotop 210Pb,” J. Oseanografi, 2015. 